\title{
MOTIVACIJA STUDENATA ZDRAVSTVENIH USMJERENJA ZA UČENJE STRANIH JEZIKA
}

${ }^{1}$ Sanja Brkić, ${ }^{1}$ Kaja Mandić, ${ }^{1,2}$ Magdalena Ramljak

${ }^{1}$ Fakultet zdravstvenih studija Sveučilišta u Mostaru

${ }^{2}$ Filozofski fakultet Sveučilišta u Mostaru

Rad je primljen 01.09.2020.. Rad je recenziran 18.09.2020. Rad je prihvaćen 29.09.2020.

\section{SAŽETAK}

Iako nastava stranih jezika općenito obuhvaća i pojmove kojima se koristi u medicini i zdravstvu, za učinkovit rad zdravstvenih djelatnika bitno je usvajanje znanja specijaliziranog za medicinsku struku. Strani jezici, pogotovu engleski i njemački jezik, posebice su važni u području biomedicine i zdravstva te njihovo poznavanje izravno djeluje na lakše prikupljanje novih znanstvenih informacija potrebnih za svakodnevni rad zdravstvenih djelatnika, a time i podiže kvalitetu zdravstvene zaštite. Svaki nastavnik se treba prilagođavati pojedinim potrebama svojih studenata, ovisno o tome dolaze li $s$ naprednijim znanjem stranoga jezika ili se radi samo o osnovama. Pristup motivaciji studenata za učenje stranog jezika je individualan i zahtijeva dodatni napor nastavnika. Uloga predavača stranog jezika nije samo predavanje sadržaja utvrđenog planom i programom, nego i konstantna motivacija i inspiracija studenata za učenje stranog jezika uz govor, čitanje, pisanje i razumijevanje.

Ključne riječi: strani jezik, studenti, zdravstvene znanosti, motivacija

Osoba za razmjenu informacija:

Kaja Mandić

E-mail: kaja.mandić@fzs.sum.ba 


\section{UVOD}

Globalizacija je dovela do značajnog povećanja potražnje za učenjem stranih jezika na visokoškolskoj razini. Posebice su visoka učilišta, kao ključni nositelji obrazovanja, dužna to podržati (1). Visoka učilišta u području biomedicine i zdravstva nisu ustanove samo od akademske važnosti već trebaju stvarati preduvjete za povezivanje zdravstvenih djelatnika na globalnom nivou kako bi pružali kvalitetniju zdravstvenu zaštitu u budućnosti. Globalno povezivanje nije moguće bez poznavanja svjetskih stranih jezika (2). Učinkovitost učenja stranih jezika uvijek se smatrala ovisnom o motivaciji i sposobnosti studenata s jedne strane te profesionalne i osobne kvalitete učitelja s druge strane. Kada su u pitanju naši prostori, najčešće se radi o motivaciji za učenje engleskog i njemačkog jezika. Veliki dio studenata na Fakultetu zdravstvenih studija (studiji fizioterapije, radiologije, sestrinstva, sanitarnog inženjerstva i primaljstva), ali i ostalim fakultetima s područja biomedicine i zdravstva poput medicine, farmacije i stomatologije, dolazi s određenim predznanjem tih dvaju jezika te su motivirani upisati jedan od njih kao zaseban predmet. Cilj ovog rada je opisati motivaciju studenata zdravstvenih usmjerenja za učenje stranih jezika.

\section{Motivacija studenata za učenje stranih jezika na studijima zdravstvenih usmjerenja}

Motivacija kao temeljna i cjeloživotna potreba kojom usvajamo navike, znanja, vještine i sposobnosti te razvijamo kreativne mogućnosti, zahtijeva određenu razinu ulaganja intelektualnog napora, koncentracije i upornosti, koji utječu na kvalitetu i kvantitetu naučenog i stečenog znanja i kompetencija (3). Postoji više vrsta definicija motivacije. Istraživanja su pokazala da je motivacija jedan od najznačajnijih čimbenika uspješnosti u učenju jezika, uz strategije koje učenik primjenjuje u učenju jezika. Od početaka istraživanja motivacije za učenje stranog jezika u drugoj polovini prošloga stoljeća do danas nastalo je nekoliko modela koji pokušavaju objasniti povezanost motivacije s uspješnošću učenja stranog jezika (4). Motivacija se definira kao skup motiva, odnosno psiholoških stanja koji pokreću i usmjeravaju ljudsko ponašanje te određuju intenzitet toga ponašanja (5). Razlikujemo dvije vrste motivacije, a to su intrinzična i ekstrinzična. Intrinzična motivacija odnosi se na osobne motive i unutarnju želju pojedinca, dok je ekstrinzična motivacija pokrenuta vanjskim čimbenicima. Intrinzična motivacija (engl. intrinsic - unutarnji, svojstven, pravi, bitan, čist) je potreba nastala iz unutarnjih pobuda, osobnih motiva i unutarnjih želja pojedinca, dok se kod ekstrinzične radi o vanjskim čimbenicima kao na primjer nagradama koje utječu na njezin razvoj (6).

Očekivano je da je motivacija učenja stranih jezika kod studenata Fakulteta zdravstvenih studija (studiji fizioterapije, radiologije, sestrinstva, sanitarnog inženjerstva, primaljstva), Medicinskog fakulteta i Farmaceutskog fakulteta veća nego kod studenata s drugih usmjerenja, a najviše iz razloga što je područje biomedicine i zdravstva više usmjereno na međunarodnost istraživanja i prikupljanje globalnih znanja. S druge strane, na našim prostorima veliku motivaciju za učenje jezika čini i to što se zdravstveni djelatnici sve više zapošljavaju u zemljama njemačkoga govornog područja. Zbog toga je očekivana motivacija za učenje navedenih jezika. Kada su u pitanju nastavnici i njihov utjecaj na motivaciju studenata za učenje, poznata su istraživanja kojima su se bavile studije u kojima su istraživači naglašavali važnost relevantnih povratnih informacija kako bi studenti bili motivirani. S druge strane, unatoč naporima nastavnog osoblja da uspostave učinkovito okruženje za učenje, neki učenici i dalje nisu motivirani za bolji uspjeh i usvajanje novih znanja iz stranih jezika $(7,8)$.

\section{Strani jezik u zdravstvenim usmjerenjima}

Iako nastava stranih jezika općenito obuhvaća i pojmove kojima se koristi u medicini i zdravstvu, za učinkovit rad zdravstvenih djelatnika bitno je usvajanje znanja specijaliziranog za medicinsku struku. Termini drugi jezik i strani jezik često se upotrebljavaju kao sinonimi i označavaju pojam nekog jezika koji nije materinski. Drugim jezikom smatra se nematerinski jezik koji se uči unutar zemlje u kojoj je 
taj jezik u uporabi, a stranim jezikom smatra se nematerinski jezik koji se uči izvan nacionalnih i teritorijalnih granica (9). Prema drugoj definiciji, strani je jezik prototipno jezik koji se ne govori u okolini gdje tko živi i djeluje. Drugi je jezik prototipno jezik koji se govori u okolini gdje tkoživi i djeluje (10).

Iako se za prvi jezik sa sigurnošću može tvrditi da je proces njegova usvajanja sličan kod svih ljudi, kao i njegov rezultat koji nas čini sposobnima služiti se prvim jezikom kao izvorni govornici, usvajanje drugog jezika i njegovi krajnji ishodi ipak su uvjetovani raznim čimbenicima (11). Strani jezik, osobito engleski i njemački, posebice je bitan u području biomedicine i zdravstva te njegovo poznavanje izravno djeluje na lakše prikupljanje novih znanstvenih informacija potrebnih za svakodnevni rad zdravstvenih djelatnika, čime se podiže i kvaliteta zdravstvene zaštite.

\section{Pregled istraživanja motivacije studenata za učenje stranog jezika}

U radu Zhang i sur. rezultati utvrđuju da instrumentalne i integrativne motivacije sudionika pozitivno utječu na njihovo znanje drugog ili stranog jezika. Daljnja analiza otkriva da je povezanost između motivacije sudionika i znanja jezika posredovana uživanjem u stranim jezicima. Nalazi idu u prilog prijedlozima za održivo učenje i poučavanje stranih jezika na sveučilištima (12). Prema Luo Z i sur., iako se anksioznost široko smatra vrstom negativnih emocija, primijećeno je da bi određene vrste ljudi mogle biti motiviranije kad se suoče s određenim stupnjem anksioznosti. Međutim, prethodna istraživanja nisu dala konačne rezultate o korelaciji anksioznosti s motivacijom u kontekstu učenja stranih jezika. Cilj tog istraživanja bio je istražiti vezu između anksioznosti i motivacije kako bi se istražila mogućnost korištenja anksioznosti za jačanje motivacije u kontekstu stranih jezika. Nalazi su otkrili da je olakšavanje anksioznosti u značajnoj i pozitivnoj korelaciji s unutarnjom i vanjskom motivacijom. $\mathrm{Uz}$ to, iscrpljujuća anksioznost također je u značajnoj korelaciji s vanjskom motivacijom. Nalazi ukazuju na mogućnosti korištenja anksioznosti za jačanje motivacije u kontekstu učenja stranih jezika, od- nosno glavno otkriće tog istraživanja jest da postoji značajna i pozitivna korelacija između anksioznosti i motivacije u učenju stranih jezika. Nadalje, unutarnja motivacija je značajno povezana s olakšavanjem anksioznosti, a vanjska motivacija je u visokoj korelaciji s obje vrste tjeskobe (13). U radu King i sur. opisana je teorija "Personal investment theory", klasična teorija motivacije koja koristi višestrani pristup kako bi razumjela kada i zašto učenici ulažu sebe u određenu domenu. „Personal investment theory" tvrdi da postoje tri ključne komponente značenja - olakšavanje uvjeta, osjećaj sebe i opaženi ciljevi - koji su presudni za razumijevanje motivacije i učenja. $\mathrm{U}$ radu se daje pregled ključnih načela teorije $\mathrm{i}$ ilustrira sinergija između te teorije i istraživanja $u$ učenju drugog i stranog jezika. Iako se teorija osobnih ulaganja rijetko koristi $u$ istraživanjima drugog i stranog jezika, navodi se slučaj kako ona može obogatiti uobičajeno teoretiziranje drugog i stranog jezika (14). U radu Lu i sur. proučavana je motivacijska naklonost 17 kineskih studenata sa sveučilišta za učenje španjolskog jezika kao sveučilišnog studija bez napuštanja studija engleskog jezika. Na temelju Q-metodologije i dopunskih intervjua, rezultati eksperimenta pokazali su da su ti kineski studenti pokazali dvije vrste motivacije za učenje stranih jezika, od kojih je jedna višejezična skupina s engleskim usmjerenjem, a druga skupina je učila samo španjolski jezik. Prva skupina imala je snažnu motivaciju za učenje engleskog umjesto španjolskog, dok je druga skupina učila španjolski s motivacijom usko povezanom s njihovim osobinama. Razne su analize primijenjene kako bi se odgovorilo na pitanja koja se odnose na grupne razlike i stavove učenika prema učenju španjolskog i engleskog jezika posredovanih individualnim, obrazovnim i socijalnim čimbenicima (15).

Cilj studije Cocca M i sur. bio je istražiti vezu između afektivnih varijabli, motivacije i vještine te procijeniti koje stavove / motivacijske domene mogu bolje predvidjeti znanje engleskog jezika na uzorku od 354 sveučilišna studenta. Istraživanje je pokazalo da su postignuća učenika značajno povezana s njihovim motivacijskim intenzitetima, njihovim odnosima prema učenju engleskog jezika i 
njihovom željom da ga nauče, kao i s njihovim mišljenjima o izvornim govornicima engleskog jezika i percepciji kvalitete tečaja engleskog. Utvrđeno je da su stav prema učenju engleskog jezika i percepcija učenika o kvaliteti tečaja engleskog jezika prediktori postignuća. Prema autorima, stvaranje kulturološki obogaćenog okruženja temeljeno na strategijama usmjerenim na učenike moglo bi utjecati na znanje učenika više nego na nastavničke sposobnosti nastavnika i njegov stav u učionici (16).

Softa $\mathrm{V}$ je u svome radu istraživao integrativne $\mathrm{i}$ instrumentalne varijable. Imao je za cilj istražiti socijalni i kulturni aspekt motivacije za učenje stranih jezika, s glavnim fokusom na engleskom jeziku, kao obveznom tečaju u službenim obrazovnim kurikulumima u Albaniji, od osnovne razine do programa master studija. Istaknuo je jezičnu integrativnost koja je povezana s pozitivnim stavovima prema članovima zajednice korisnika ciljnog jezika i željom za stupanje u interakcije i emocionalnom identifikacijom za usvajanje njihovih društvenih uvjerenja i postupaka $(17,18)$.

Instrumentalna uloga stranog jezika povezana je pak sa željom studenata da steknu prepoznavanje, socijalni status ili materijalnu korist od korištenja jezika i odnosi se na učenje jezika iz konkretnih razloga, poput karijere, boljeg obrazovanja ili visoke ekonomske perspektive, povezanih s jezičnim usavršavanjem (19).

U radu Ivanova M i sur. u istraživanju je sudjelovalo 230 učenika druge godine koji su stekli diplomu moskovskog državnog sveučilišta za proizvodnju hrane, a među ispitanicima je bilo 143 žene i 87 muškaraca u dobi od 18 do 20 godina, koji su državljani Ruske Federacije. Eksperiment je bio podijeljen u tri faze. Rezultati tog istraživanja pokazuju da bi autoritarni i demokratski stil interakcije učitelj-učenik mogao pozitivno utjecati na obrazovno ponašanje učenika i akademske sposobnosti, dok provedba liberalnog stila interakcije učitelj-učenik dovodi do motivacije. Istodobno je demokratski stil, suprotno hipotezi autora, izazvao uglavnom ne unutarnju nego vanjsku motivaciju, dok su autoritarni stilovi značajno aktivirali unutarnju motivaciju (20). U istraživanju Hromove i sur., a koje je posvećeno evaluaciji dimenzija motivacije učenika za učenje stranih jezika, sudjelovala su 132 studenta (21 muškarac i 111 žena). Istraživanje je uključivalo kvalitativnu analizu podataka odgovora učenika. Kvantitativna analiza podataka dobivenih iz upitnika prilagođenog Gardnerovom modelu za testiranje stavova/motivacije definirala je motivacijske orijentacije učenika. Studija je otkrila rastući trend želje učenika za intelektualnim razvojem u kombinaciji s praktičnim pristupom učenju stranih jezika. Definirani su vodeći motivi za učenje jezika: nedostatak samopouzdanja i pozivanje na opće vrijednosti prihvaćene u društvu. Najvažnije implikacije za učitelje uključuju praćenje percepcije njihovih učenika i stvaranje učinkovitog obrazovnog okruženja, podizanje samopouzdanja i odgovornosti učenika (20).

\section{ZAKLJUČAK}

Poučavanje stranog jezika bitno je na zdravstvenim studijima zbog prilagođavanja potrebama koje iziskuje terminologija pojedinog područja znanosti. Bitno je i zbog činjenice da je sama edukacija zdravstvenih djelatnika nemoguća bez korištenja znanstvenih informacija na engleskom jeziku. S druge strane, većina studenata želi naučiti njemački jezik jer je vrlo tražen od poslodavaca. Poučavanje stranih jezika u sveučilišnom sustavu ima cilj pružiti studentima mogućnost da aktivnom interkulturnom komunikacijom postanu dijelom međunarodnog obrazovnog i radnog prostora u okviru svojih profesionalnih i znanstvenih aktivnosti. Osim navedenog, svaki se nastavnik mora prilagođavati pojedinim potrebama svojih studenata, ovisno o tome dolaze li s naprednijim znanjem stranog jezika ili se radi samo o osnovama. Činjenica je da studenti dolaze na nastavu stranog jezika s različitim razinama znanja. Samim time pristup motivaciji studenata za učenje stranog jezika je individualan i zahtijeva dodatni napor nastavnika. Posao predavača stranog jezika ne uključuje samo predavanje sadržaja utvrđenog planom i programom, nego i kontinuiranu motivaciju i inspiraciju studenata za učenje stranog jezika uz govor, čitanje, pisanje i razumijevanje. 


\section{LITERATURA}

1. Zhang H, Dai Y, Wang Y. Motivation and Second Foreign Language Proficiency: The Mediating Role of Foreign Language Enjoyment. Sustainability. 2020;12(4):1302.

2. Šimić Lj, Šimić J. Značaj osnivanja visokoobrazovnih institucija biomedicinskih znanosti na Sveučilištu u Mostaru. Motrišta. 2017; 93/94: 227-235. preuzeto sa: https://www.ceeol.com/ search/article-detail?id=514630 (18.09.2020.)

3. Krstinić M, Pauković M. Ekstrinzična i intrinzična motivacija za učenje stranog jezika u poslovnom okruženju. Obrazovanje za poduzetništvo - E4E : znanstveno stručni časopis o obrazovanju za poduzetništvo, 2020; 10(1):7683.

4. Bradarić-Jončić $\mathrm{S}, \mathrm{Mohr}$ Nemčić R. Motivacija u učenju Hrvatskog znakovnog jezika (HZJ), Logopedija. 2015;5(2):10-17.

5. Medved Krajnović M. Od jednojezičnosti do višejezičnosti. Zagreb: Leykam international. 2010.

6. Rheinberg F. Intrinsische Motivation und Flow-Erleben. In Heckhausen J. und Heckhausen H. (Eds) Motivation und Handeln (3. Aufl., in Vorbereitung) Berlin: Springer. 2004.

7. Hromova N. Students' perceptions and motivation for learning foreign languages. Advanced Education 2019;6:76-83.

8. Hattie J, Timperley H. The power of feedback. Review of Educational Research, 2007;77: 81112.

9. Ćoso Z. Problematika ovladavanja jezikom. Croat Slav Iadert 2016; 12(2):493-512.

10. Jelaska Z. Ovladavanje jezikom: izvornojezična i inojezična istraživanja. Lahor. 2007;1(3):86-99. Dostupno na: https://hrcak.srce.hr/20658 Preuzeto (08.11.2020).

11. Kolić N. Uloga motivacije i višejezičnog iskustva u ovladavanju ukrajinskim jezikom. Sveučilište u Zagrebu. 2020.
12. Zhang H, Dai Y, Wang Y. Motivation and Second Foreign Language Proficiency: The Mediating Role of Foreign Language Enjoyment. Sustainability. 2020;12(4):1302.

13. Luo Z, Subramaniam G, O'Steen B.Will Anxiety Boost Motivation? The Relationship between. Anxiety and Motivation in Foreign Language Learning. Malaysian Journal of ELT Research.2020;17(1):53-71.

14. King Ronnel B, Yeung S. Personal investment theory: A multi-faceted framework to understand second and foreign language motivation. System, 2019;86:102123.

15. Lu X, Zheng Y, Ren, W. Motivation for Learning Spanish as a Foreign Language: The Case of Chinese L1 Speakers at University Level. CÍRCULO de Linguística Aplicada a la Comunicación; Madrid. 2019;79:79-98.

16. Cocca M, Cocca A. Affective Variables and Motivation as Predictors of Proficiency in English as a Foreign Language. Journal on Efficiency and Responsibility in Education and Science, vol. 2019;12(3):5-83.

17. Dörnyei Z. Motivation and motivating in the foreign language classroom. The Modern Language Journal. 1994;78:273-284.

18. Csizer K, Dörnyei Z. The internal structure of language learning motivation and its relationship with language choice and learning effort. The Modern Language Journal.2005;89;19-36.

19. Softa V. Social and Cultural Aspect in Foreign Language Motivation Defined by Integrative and Instrumental Factors. European Journal of Sustainable Development, 2019;8(5):93,

20. Ivanova M, Shlenskaya N, Mekeko N, Kashkarova T. The Influence of the Teaching Style of Communication on the Motivation of Students to Learn Foreign Languages. Journal of Language and Education, 2019;5(2):67-77. 


\title{
MOTIVATION IN FOREIGN LANGUAGE LEARNING FOR STUDENTS OF HEALTH SCIENCES
}

\author{
${ }^{1}$ Sanja Brkić, ${ }^{1}$ Kaja Mandić, ${ }^{1,2}$ Magdalena Ramljak \\ ${ }^{1}$ Faculty of Health Studies University of Mostar \\ ${ }^{2}$ Faculty of Humanities and Social Sciences University of Mostar
}

\begin{abstract}
Although foreign language teaching generally includes terms used in medicine and healthcare, the acquisition of specialized medical terminology is important for effective work of healthcare professionals. Foreign languages, especially English and German, are particularly important for the field of biomedicine and healthcare since they directly affect the process of collecting information necessary for daily work activities of healthcare professionals, thus improving the overall quality of healthcare. Every teacher should adapt to individual needs of students, regardless of advanced or basic knowledge of the foreign language. The approach to motivation of students for foreign language learning is individual and requires additional teacher effort. The role of foreign language teachers is not only to teach the content determined by the curriculum but constantly motivate and inspire students for foreign language learning through speaking, reading, writing and comprehension.
\end{abstract}

Key words: foreign language, students, health sciences, motivation

Correspondence:

Kaja Mandić

E-mail: kaja.mandic@fzs.sum.ba 